\title{
310. Subphrenische Abscesse nach Organperforationen und Oberbaucheingriffen
}

\author{
H. Fleischer-Solingen
}

\section{Subphrenic Abscesses after Organ Perforations and Epigastric Operations}

Summary. In our clinic 29 subphrenic abscesses were seen in the past 11 years, mainly after stomach resection (15 after stomach operations). 3 developed after gallbladder empyema, 2 after choleoystectomy and the remainder after splinter injuries, appendicitis, hemicolectomy and intussusception ileus. The clinical symptoms are often quite uncharacteristic and only aimed examination leads to a correct diagnosis. Our treatment is purely operative but 8 out of 26 evaluated cases died of septic complications.

Zusammenfassung. In unserer Klinik konnten in den letzten $11 \mathrm{Jahren} 29$ subphrenische Abscesse beobachtet werden, die vorwiegend nach Magenresektionen (15 bei Eingriffen an diesem Organ) aufgetreten waren. 3 weitere entstanden bei Gallenblasenempyemen, 2 nach Cholecystektomie, der Rest nach Splitterverletzungen, Appendicitiden, Hemikolektomie und Invaginationsileus. Die klinische Symtomatik ist oft sehr uncharakteristisch und nur die gezielte Untersuchung führt zur richtigen Diagnose. Die Therapie ist bei uns eine rein operative, trotzdem verstarben 8 von 26 ausgewerteten Fällen an den septischen Komplikationen.

\section{Hämobilie als Komplikation nach Eingriffen an der Gallenblase, Gallenwegen und Magen *}

\author{
o. GTERSBERG* und F. W. SchILDBERG-Köln
}

Haemobilia as a Complication Following Operations on the Gallbladder, the Bile Ducts and the Stomach

Summary. In 1957 at the Surgical University Clinic, Marburg, and in 1964 to 1971 at the Surgical University Clinic Cologne-Lindenthal, six patients had to be treated for haemobilia after operations on the biliary ducts and the stomach (Fig. 1). In four cases the cause of the bleeding was an aneurysm of the hepatic artery which had perforated into the hepatic duct. The aneurysm developed as a result of an iatrogenic injury or through vascular erosion due to infection or insertion of a catheter. In one case it was due to a trans-hepatic drainage inserted in the hepatic duct, in another case intra-operative probing of the bile ducts with a Fogarty catheter caused the haemobilia.

The diagnosis of haemobilia (Fig.2) is based on the clinical picture of rightsided pain in the upper abdomen, haematemesis, melaena and recurrent jaundice and is confirmed by selective coeliacography. In the surgical treatment (Fig.3) of haemobilia priority has to be given to preserving and restoring of blood vessels to maintain the liver circulation. A ligature of the hepatic artery in the region of the art. hepatica communis is permissible. Nearer to the liver the ligature of the

\footnotetext{
$\star$ Abbildungen hier nicht wiedergegeben.
} 